\title{
The Development of Learning Material for Seminar on English Language Teaching Course Based on Flipped Learning
}

\author{
Masitowarni Siregar, Nora Ronita Dewi, Safrida Lubis \\ Universitas Negeri Medan, Medan, Indonesia \\ siregarmasitowarni@yahoo.com
}

\begin{abstract}
This study amis at establishing instructional material for the Subject of Seminar on English Language Teaching based on Flipped Learninng. In English Educational Study Program fifth semester students students of English Educational Study Program, FBS, UNIMED. The study was conducted by utilizing Research and Developmental Study There were three phases realized in this study: : First Survey and Evaluation Phase, second designing the material and finally validating theinstructional material. Based on the phases of the study followed, the following topics of instructional material were developed ; Foundation of Seminars, Some Key Terms s of Seminars and Paper Presentations, Analyzin Topics for Seminar, Working out Pertinant Topics, Establising Paper Outline, Writing Paper Draft, Editing and Finalizing Paper, Designing Paper Presentations, Developing Power Point Presentation, Rehearsing Presentation, Paper Presentation, Running Productive Seminar. The feasibility test of teaching materials by the specialist. The findings indicated that theoutcome of the study established were suitable pertinent and fit in with the students of English Education Study Program with the mean 4.32.The material was upload to E-Learning FBS UNIMED to be utilized by the students.
\end{abstract}

\section{Keywords}

Seminar on ELT; flipped learning

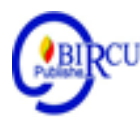

\section{Introduction}

The competency in making presentation in a seminar is a crucial skill nowadays. According to Ghofur (2019) a good strategy to improve competencies in core subject and to achieve the descriptors of Indonesian National Qualification Framework is not by emerging new courses related to 21 st century skills, but by integrating 21 st century skills in learning designs of every course. Thus, the number of course that support the core subject will be sufficient to equip student's competency in the core subject. Therefore the students of English Educational study program as candidate teacher are equipped with the subject of Seminar on English Language teaching. Through this subject, students are expected to have knowledge and skills their scientific endeavor as a result of their opinion as well their research in a broader sense. Seminar on English Language teaching is provided in the fifth semester in the Curriculum English Educational Study Program.

Although Seminar on English Language teaching subject is a course in the curriculum, the students' achievement is not satisfactorily so far. The student's ability both in writing paper and in giving presentation is still low.

Although Seminar on Language Teaching subject is a course that always appears in the English Education curriculum, so far the results have not been maximized. The ability of students to write articles and present their articles is still low. This might be caused by several things. First, the lecturer does not seem to have the same knowledge and competence relative to the competence of the seminar on language teaching itself. Second, in the process 
of learning seminars on language teaching, lecturer only tend to focus on the material as it is, so it is not structured and up to date with the current conditions. Third, lecturer have not used the material maximally in the online network, both YouTube and e-books.

With the conditions above it can be understood why the ability of students in the Seminar on Language Teaching courses is still low, this is one of them due to the lack of maximum teaching material used by lecturer.

Referring to the above reality, the development of online resource-based Seminar on Language Teaching course materials is very urgent and important to be studied and developed in order to produce maximum competence. By developing online-based teaching materials, it is expected that the quality of students in conducting seminars is as expected. Besides that, standard materials will be available which can be used by lecturers and other related parties.

Referring to the background, the problems formulated in the study can be formulated as follows: "How to develop teaching materials on Flipped Learning-based Seminar on Language Teaching courses for students of English Department?"

The purpose of this research is to develop teaching materials on Flipped Learningbased Seminar on Language Teaching for students of English Department.

This research will develop teaching materials on Flipped Learning-based Seminar on Language Teaching for students of English Department which are validated by peers and continued with a team of experts.

This research can increase the knowledge and appearance of disseminating scientific work both its research results and its opinion to a wider reader through the use of teaching materials on seminar on language teaching based on flipped learning as the output of the study. This research can become the recommendation in conducting next study in similar issues.

\section{Review of Literature}

\subsection{The Theory and Stages in the Establishment of Instructional Materials}

There are three principles needed in the development of teaching materials (Sadiman et al., 2003). The three principles are relevancy, consistency, and adequacy. Relevancy means interconnectedness. Consistency means constancy-fixed. The adequacy means quantitatively means that the material is sufficient to be studied.

There are several procedures that must be followed in the development of teaching materials (Sadiman, 2004). The procedure includes: (1) understanding the content standards and competency standards of graduates, syllabi, semester programs, and learning implementation plans; (2) identifying the type of learning material based on understanding the first point; (3) material mapping; (4) determining the form of presentation; (5) preparing the structure (framework) for presentation; (6) reading the source book; (7) drafting the teaching materials; (8) revising (editing) the teaching materials; (9) testing the teaching materials; and (10) revising and final writing (finalization).

Another thing that is no less important is that in preparing the teaching materials it is necessary to pay attention to the suitability of the material, the suitability of the methods and relevant media, and can support the learning process. According to Tarigan and Tarigan (1986:

20) the criteria for studying the teaching materials include: (1) the applicable curriculum; (2) subject characteristics (relevant knowledge); (3) the relationship 
between curriculum, subjects and teaching materials; (4) the basics of the development of teaching materials; (5) the quality of teaching materials; (6) principles for developing workbooks; and (7) selecting of workbooks. The assessment of teaching materials according to Supriadi (2001: 9) includes: "the quality of the contents of the book, its suitability with the curriculum, the language used including its presentation and readability, graphics, and book safety".

\subsection{Flipped Learning}

Flipped Learning or Flipped Classroom is a learning model that "flips" traditional methods, where material is usually given in the classroom and students do assignments at home. The concept of Flipped Classroom includes active learning, student involvement, and podcasting. In Flipped Learning or flipped classroom, the teachers instruct the students to watch vidio before the class begin. Instead, the interaction in the classroom are directed to excaging between the students and do the rehearsal or task.

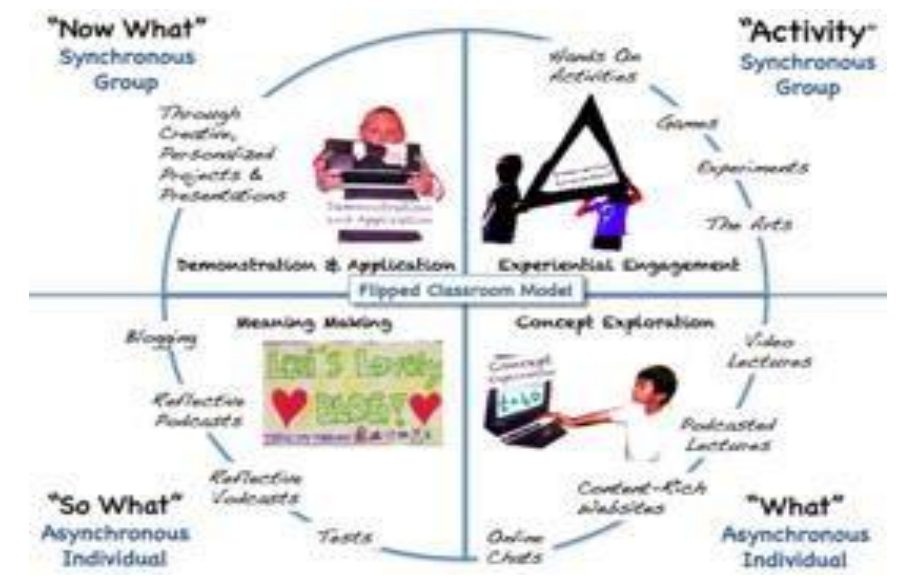

Figure 1. The lecturer acts as a coach or adviser

The application of the flipped learning model or flipped classroom has many advantages over the traditional learning model. The availability of material in the form of videos gives students the freedom to stop or repeat the material at any time in parts they do not understand. In addition, the use of classroom learning sessions for projects or group assignments makes it easy for students to interact and learn from each other.

Furthermore, flipped learning consisted on four basic components as shown in Figure 2 below, which are flexible environment, learning culture, intentional content and professional education.

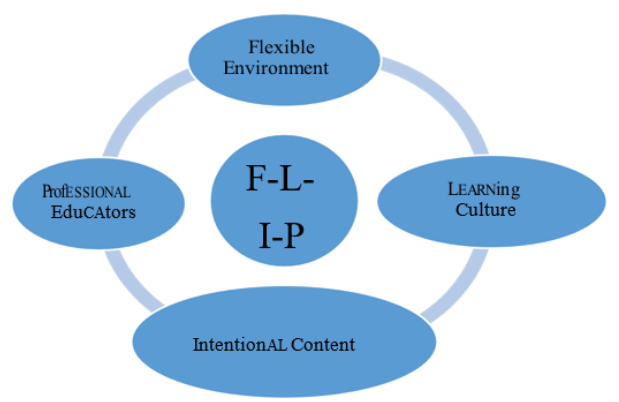

Figure 2. Flipped Learning Four Pilars 
Flexible Learning in Flipped learning is important. In this case, it means that both lecturers and students can access teaching materials whenever and wherever needed which makes students become autonomous learners.

Learning culture is intended to change from the roles of students and lecturers. The role of students becomes more active to be more responsible in building the understanding in learning material.

Intentional content refers to the content of the material students will learn as stated by Chang (2016: p.5) "in my flipped classrooms, various materials are used by the students : textbooks, PowerPoint slides, video clips, practice tests, and discussion forums. For the purpose of using the notion of natural situation individual and group tasks aare set to be used in the classroom."

According to Chang, teacher can aks the students to review teaching learning material befire the class. in Flipped learning these could be in forms of textbook, ppt slides, videos, rehearsal book. Furthermore, the lecturer designs group and individual assignments for students to apply in the reality situation.

The final pillar of flipped learning is professional educators. The demand for flipped learning teaching materials where lecturers must prepare to share various kinds of online resources and respond to students' needs makes lecturers become professionals. The four pillars of flipped learning above will be the basis for developing Seminar teaching materials on Language Instruction.

\subsection{Seminar on Language Training Courses}

Seminar on Language Teaching Course aims to help students: 1) understand the theory of writing scientific articles, including research proposals, properly; 2) able to practice the theoretical knowledge to be able to produce their own scientific articles that are worthy of publication through scientific seminars/journals and, specifically for research proposals, deserve to be continued with research; and, 3) able to speak well at the seminar, both as a speaker and as a seminar participant.

In accordance with its objectives, this Seminar on Language Teaching and Learning course examines issues related to advanced scientific writing, both theory and practice, and speaking theory and practice. For this reason, this course discusses the following matters: Eight Keys to a First Rate Paper, Choosing and Focusing your Topic, Researching your Topic, Creating the First Draft, Preparing the Final Paper, Grammar and Style Tips, Works Cited and Works Consulted Lists, Illustrating your Paper, Typing and Word-Processing Guidelines, Giving an Oral Presentation, Writing and Research, Research Proposal Writing, and Sample Term Papers and Reports.

Learning Competencies of this course: Following this course, students are expected to understand the Seminar on Language Teaching as a theory and practice as a basis for them to not only give critical appreciation of people's writings but also be active as producers of their own writings, as writers, especially good scientific papers and research proposals that are feasible to be continued with research. Special Competencies By joining this course, students can: 1) analyze the scientific papers such as research results and critically conceptual studies; 2) produce the scientific papers themselves properly and correctly, especially scientific papers and research proposals; and, 3) publish their writings in relevant media or present them at scientific seminars (speaking) well. 


\section{Research Methods}

This study utilised the Research and Development (R \& D) paradigm. This study was implemented in 3 (three) stages where each stage has its own goals and outcomes.

The first stage - at this stage a survey and evaluation will be carried out to 1) find out the objective conditions regarding the teaching materials for seminar on language teaching course

2) obtain data and information about Flipped Learning based instructional materials for students of English Educational Study Program ( EESP). Output: instructional materials based on Flipped Learning to be used by English Educational Study Program students.

Next is designing and developing teaching materials based on Flipped Learning for EESP students . In the process of the development of teaching materials based on Flipped Learning for EESP students, reviewing assessment instruments by peers, and revising the teaching materials based on Flipped Learning for EESP students. Output: Flipped Learning based teaching material for EESP students which have been assessed by colleagues.

The last phase is the instructional material designed are assessed or validated by expertise. The expert team consisted of two experts in the field of seminar on language teaching. Last product: validated teaching book .

This study was conducted in the English Educational Study Program, Faculty of Languages and Arts, Universitas Negeri Medan. Data collection techniques consisted of documentation, interviews, and questionnaires. Data collecting instruments consist of documentation sheets, interview guidelines, and questionnaires. Method of analyzing data used are qualitative approach analysis. The whole scenario of research can be seen in the following figure. 


\section{Stage 1}

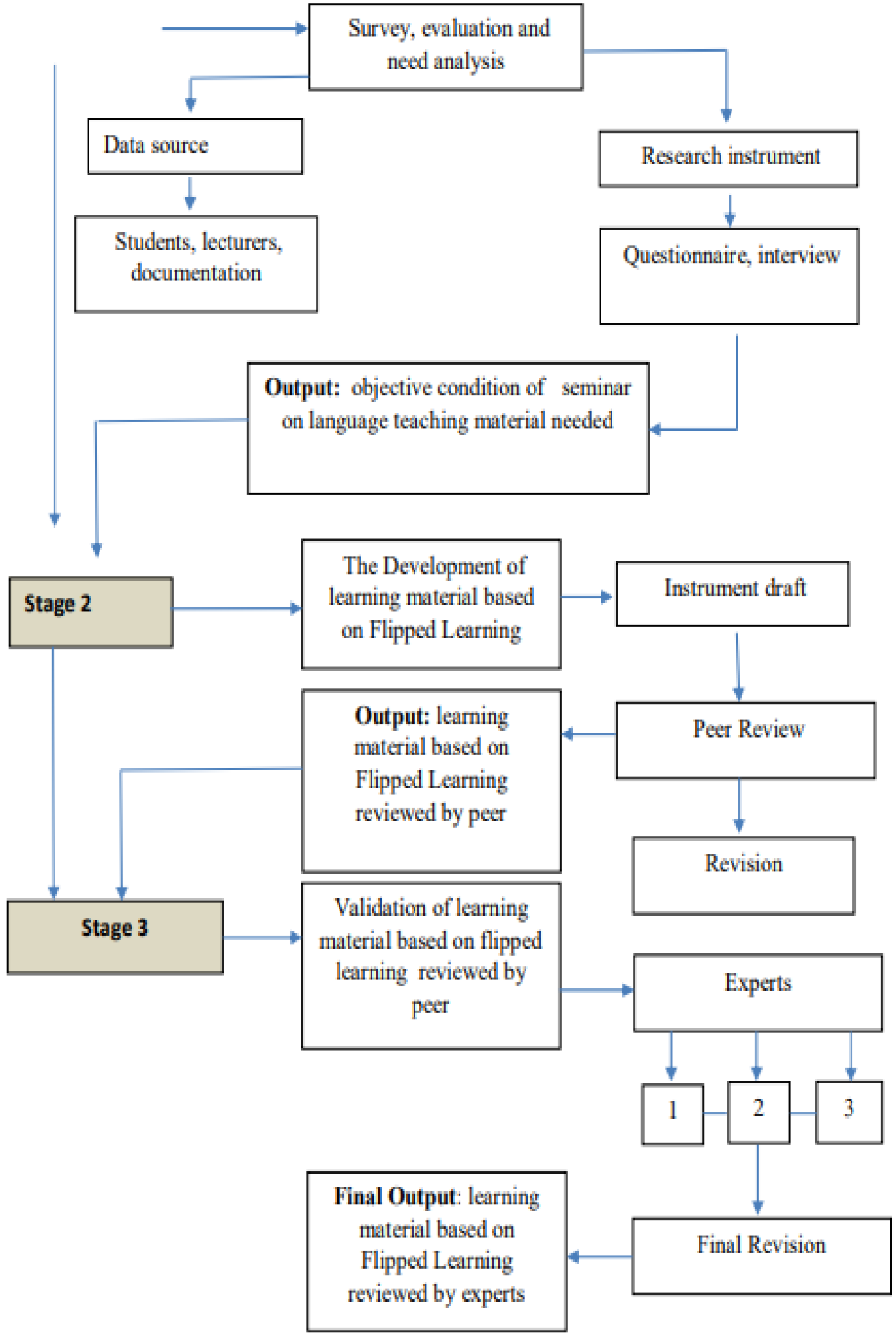

Figure 3. Research Flow chart 
The flow of research will be conducted to develop Seminar on Language Teaching Material based on flipped learning is shown in Fishbone Diagram below.

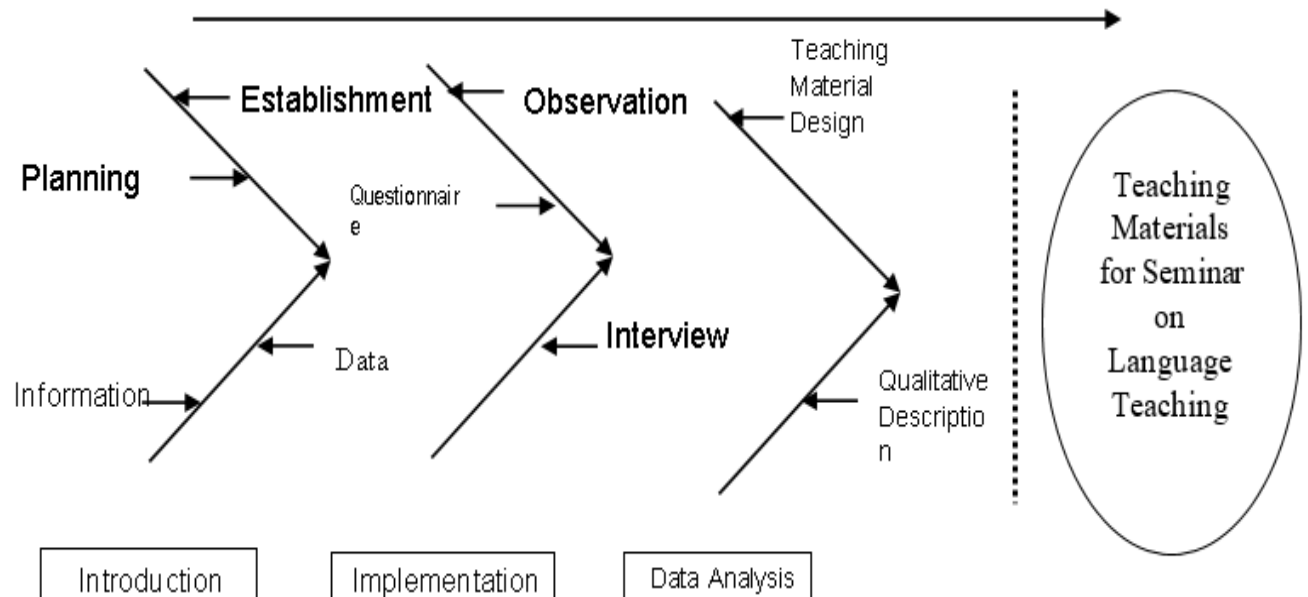

Figure 4. Fishbone Research Flow Chart

\section{Discussion}

\subsection{Research Result}

The research aimed at developing seminar on language teaching materials based on flipped learning is carried out using the Research and Development (R\&D) method. The study was conducted in 3 (three) phases in which each phase has its own goals and outcomes.

The first stage - at this stage a survey and evaluation will be carried out to 1) find out the objective conditions regarding the teaching materials for seminar on language teaching course

2) obtain data and information about Flipped Learning based instructional suppliesfor EESP students. Output: instructional supplies Flipped Learning for EESP students urgency.

Next phase is designing and developing teaching materials based on Flipped Learning for EESP students. In the process of the development of instructional supplies based on Flipped Learning for EESP students, reviewing assessment instruments by peers, and revising the teaching materials based on Flipped Learning for EESP students. Output: Flipped Learning based lecture material for EESP students that have been assessed by colleaagues.

Last phase is the validation of Flipped Learning-based Seminar on Language Teaching course for EESP students by a team of experts. Last product: validated teaching book . The expert team consisted of two experts in the field of seminar on language instruction. Research is in the process of making and assessing teaching materials on various topics related to Seminar on Language Teaching course such as were The Nature of Seminars, The Foundation and Key Terms of Seminars and Scientific Article Dissemination, Understanding Seminar Themes, Establishing Applicable Issues, Writing Article Draft, Developing Article Draft, Editing and Finalizing Paper, Scheming Paper Presentations, Preparing Power Point Presentations, Excercising Presentations, Paper Presentations, and 
Excecuting high-yielding Seminars. This research is also in the validation stage which states that the product of research established are suitable, pertinent and fitting in the need of students of the English Language Program with an average mode (4.32). Then the teaching material has been included in FBS Unimed E-learning.

\subsection{Output Achieved}

The Output achieved in this study were teaching materials on seminar on language teaching based on flipped learning and publishing endeavor articles in national indexed publication.

The study came up with the product of teaching materials which have been assessed by resource persons. This research is also in the validation stage which states that the product of research established are suitable, pertinent and fitting in the need of students of the English Language Study Program with an average mode (4.32). Then the teaching material has been included in FBS UNIMED E-learning.

Accodingly the next stage is to publish at a international seminar namely the I Unimed ISLALE seminar on November 14 and is in the process of waiting for outcome of the publication of a national accredited journal.

\section{Conclusion}

The purpose of this endeavour was to establish the teaching supplies for Seminar on Language Instruction based on Flipped Learning. The study was intended to come up with the product of the instructional supplies based on the paradigm of Flipped Learning Seminar on Language Training and the product has been standardized by resource person .

Based on the results of research conducted, the fifth semester students in the English Educational Study Program FBS UNIMED really need teaching supplies for seminar on language teaching based on flipped learning that can improve students' knowledge and ability in conducting seminars on scientific work through research or opinions from the author itself. The teaching material produced has been validated to be able to achieve the learning objectives with the results of validation which states that the teaching materials developed are suitable, pertinet and fitting with the need of EESP students with the mean of (4.32). Then the teaching material has been uploaded in FBS UNIMED E-learning. The product of this research have produced flipped learning-based teaching materials and publishing articles on the results of nationally accredited research.

The suggestions of this research were: 1) this research can be used as a reference in teaching seminar on language teaching for fifth semester students. 2) Instructional material produced in this study become a source of learning in seminar on language teaching course. 3) This research can be used as a reference to conduct research and come up with more perfect endeavor findings.

\section{References}

Arief S Sadiman, et al. (2003). Media pendidikan, pengertian, pengembangan, dan pemanfaatannya.Jakarta : CV. Rajawali Pers.

Arikunto, S. (1993). Suatu Pendekatan Praktek Edisi Revisi II. Jakarta: Penerbit PT. Rianka Cipta

Chang,S.D.(2016).“TheMarriageofConstructivismandFlippedLearning”. Diunggah Mei 
2,2019http://files.eric.ed.gov/fulltext/ED565608.pdf.

Ghofur, A. Kisyani, Yulianto, B. (2019). Teaching Writing and Twenty First Century Skills Using Guided Autonomous Learning Designs. Budapest International Research and Critics Institute (BIRCI-Journal), 2 (4); 495-505.

Kurikulum Prodi Pendidikan Bahasa Inggris,2018.Jurusan Bahasa danSastra Inggris. FBS Unimed.

Prastowo, Andi. (2015). Panduan Membuat Bahan AjarInovatif. Yogyakarta: Diva Press. Sadiman, Arief. (2004). Pendayagunaan Teknologi Informasi dan Komunikasi untuk

Pembelajaran.

Seminar on Language Teaching. Silabus Mata Kuliah 2018.Tim Dosen.Prodi Pendidikan Bahasa Inggris.Jurusan Bahasa dan Sastra Inggris FBS.Universitas Negeri Medan

Sugiyono. (2006). Metode penelitian Kuantitatif, Kualitatif dan R\&D. Bandung: Penerbit Alfabeta.

Thaichay, T. \& Sitthitikul, P. (2016). "Effects of the Flipped Classroom Instruction Language Accuracy and Learning Environment: A Case Study of Thai EFL

Upper-Secondary School Students".

Zulkarnaini. (2009). Teknik Pesnyusanan Bahan Ajar. [online]. Tersedia: http://zulkarnainidiran.wordpress.com/2009/06/28/131/ [9 April 2012].http://net.educause.edu/ir/library/pdf/eli7081.pdfhttp://learnspark.blogspot.co $\mathrm{m} / 2012 / 09 /$ flipped-classroom.html 